ORIGINAL PAPER

\title{
Molecular Characterization of Enteroviruses Isolated from Acute Flaccid Paralysis Cases in Poland, 1999-2014
}

\author{
MAGDALENA WIECZOREK* and ARLETA KRZYSZTOSZEK \\ National Institute of Public Health - National Institute of Hygiene, Department of Virology, Warsaw, Poland
}

Submitted 18 December 2015, revised 10 May 2016, accepted 20 May 2016

Abstract

Enteroviruses (EVs) are among viral pathogens that can cause acute flaccid paralysis (AFP). This study represents an overview of EVs isolated through AFP surveillance in Poland between 1999 and 2014. The presence of enteroviruses was studied in stool samples that were collected from 747 AFP cases and their asymptomatic contacts. Fifty five (6.12\%) cases of AFP were associated with enterovirus isolation. Out of the 55 positive cases, 40 were associated with detection of enterovirus in patient, and 15 with detection of EV in healthy contact, without positive detection in paralytic patient. Polioviruses were isolated from 35 AFP cases. The results of this study showed that about 43.6\% of positive AFP cases were found in association with the isolation of non-polio enteroviruses (NPEV). A total of 12 different types of the species B were detected (CVA9, CVB1, CVB3, CVB4, CVB5, E3, E4, E9, E11, E13, E30), and one additional isolate represented the species enterovirus A (EV71). Among the 12 serotypes of species B, CVB3 and CVB5 were more frequently detected than others, representing $40 \%$ of the characterized isolates, followed by CVB4 (16\%), E4 (8\%), and E11(8\%). Phylogenetic analysis revealed that strains from Poland had the closest genetic relationship with isolates previously identified in Europe (France, Finland, Denmark, Moldova) but also in other parts of the world (Tunisia, China, USA), suggesting wide distribution of these lineages. The paper provides information about NPEV circulation in Poland in the past 16 years, about its association with the AFP and it indicates the need for monitoring NPEV circulation even after the eradication of poliomyelitis.

Ke y words: acute flaccid paralysis, coxsackieviruses, enteroviruses, poliovirus

\section{Introduction}

Acute flaccid paralysis (AFP) is a clinical syndrome characterized by rapid onset of weakness, which has many infectious and non-infectious causes, including viruses, bacteria, toxins, and systemic disease. AFP is the most common sign of acute polio, nationwide acute flaccid paralysis surveillance is the gold standard for detecting cases of poliomyelitis. This syndrome is also associated with a number of other viral pathogens, including non-polio enteroviruses (NPEVs), flaviviruses and adenoviruses, among others (Ooi et al., 2003; Saad et al., 2005). Several NPEVs have been isolated from cases associated with paralytic disease, including coxsackieviruses (types A 2-11, 14, 16, 21 and 22; and types B 1-6); echoviruses (types 1-4, 6, 7, 9, 11, 14, 16-19 and 30 ) and enteroviruses (types 68, 70, 71, 77, 89-91, 93, 99, 102, 104) (Shaukat et al., 2013; Angez et al., 2015).

Human enteroviruses (polioviruses and non-polio enteroviruses) are members of the Picornaviridae family, a large and diverse group of small RNA viruses characterized by a single-positive-strand genomic RNA. They are classified into four species: enteroviruses A, B, $\mathrm{C}$ and $\mathrm{D}$. More than 100 serotypes are described. They affect millions of people worldwide each year, and are often found in the respiratory secretions and stool of an infected person. Peak EV transmission occurs in the summer and fall in temperate climates. Enteroviruses enter the host by crossing the intestinal mucosa. The outer capsid, which is composed of major structural proteins VP1-VP3, is responsible for host-receptor binding and viral entry into the host cell. Important serotype-specific neutralization epitopes are located on the most external and immunodominant protein VP1 (Halim and Ramsingh, 2000). Molecular methods based on the amplification and sequencing of the VP1 coding region have been used for determination of serotype and for molecular characterization of enteroviruses.

Diagnosis of enterovirus associated with acute flaccid paralysis cases is based on classical virological procedures. Tests for virus isolation are performed on two adequate stool specimens collected within 14 days of

\footnotetext{
* Corresponding author: M. Wieczorek, National Institute of Public Health - National Institute of Hygiene, Department of Virology, Warsaw, Poland; e-mail: mrechnio@pzh.gov.pl
} 
onset of paralysis, and 24-48 hours apart, from each AFP patient aged less than 15 years. The serotype of strains isolated by this method is identified with neutralizing assay using type-specific antisera (WHO, 2004).

The most common cause of AFP, virus polio, is nearly completely eradicated as a result of global immunization efforts. During the last years, greater attention has been focused on non-polio enteroviruses, which can also cause a polio-like paralytic disease. Several cases of paralysis were reported with coxsackieviruese in Scotland (Grist and Bell, 1984). EV 71 has caused epidemics of acute flaccid paralysis in recent years (especially in Asia), often in association with hand, food and mouth disease (Liu et al., 2000). EV 68, which primarily causes respiratory infections, is another serotype that may cause AFP. Paralysis cases associated with enterovirus 68 have been almost unseen, until now (Lang et al., 2014). These cases illustrate the importance of appropriate screening for polio and non-polio enteroviruses.

The aim of this study was the molecular characterization of non-polio enteroviruses isolated from AFP cases registered in Poland in the period 1999-2014, identification prevalent serotypes, and determination of their genetic diversity.

\section{Experimental}

\section{Materials and Methods}

Virus isolation in cells. In this study, stool samples were obtained from 747 children $(<15$ years) with AFP and from their close contacts, during a 16-year period (1999-2014). Stool samples were processed according to the standard procedure recommended by WHO (WHO, 2004). Samples were inoculated onto 2 cell lines, human rhabdomyosarcoma (RD) and a mouse cell line carrying the poliovirus receptor (L20B). RD and L20B cells were cultivated in minimal essential medium (MEM) supplemented with 10\% foetal bovine serum (FBS). A volume of $200 \mu \mathrm{l}$ of sample was inoculated into tubes with RD and L20B cells. The tubes were incubated at $36^{\circ} \mathrm{C}$ and were examined daily. After 7 days, the tubes were frozen and thawed and repassaged, and another 7-day examination was performed. Each specimen underwent two passages in RD and L20B cells. The development of EV-like cytopathic effect was monitored during 14 days post inoculation. Isolates were initially characterized by a neutralization assay using poliovirus specific antisera and pooled antisera against most NPEVs (National Institute for Public Health and the Environment, The Netherlands). All detected NPEVs were sequenced.

RNA isolation and RT-PCR. Viral RNA was extracted from NPEV positive cell culture supernatant using QIAamp Viral RNA Mini Kit (Qiagen) following the manufacturer's instructions. Extracted RNA was amplified by a combined RT and first round PCR using Superscript III (Invitrogen) followed by a second amplification reaction with nested primers for species B VP1 sequences and PCR cycling times and temperature as previously described (Leitch et al., 2009). One sample, negative for species $\mathrm{B}$, was amplified with primers for species A VP1 sequences according enterovirus surveillance guidelines (WHO, 2015). Amplified products were analysed in 1.5\% agarose gels, GelRed-stained, and examined under a UV DNA transilluminator.

Sequencing and sequence analysis. The resulting DNA templates were processed in cycle sequencing reaction with a BigDye 3.1 according to manufacturer's protocol. The product of sequencing reaction was run in an automated genetic analyser (Applied Biosystems, model 3730). The resulting sequences were manually edited using BioEdit program and examined to identify the closest homologue using BLAST software (http:// www.ncbi.nlm.nih.gov/BLAST/). The sequences of isolated strains (region VP1) were aligned with the reference strains. Molecular and phylogenetic analyses were conducted using MEGA version 6.06. Sequences have been assigned GenBank accession numbers.

Statistical analysis. To identify statistical significance, a Student's $t$-test analysis was performed online (http://www.physics.csbsju.edu/stats/). Results with $\mathrm{p}$ values of less than 0.05 were considered significant.

\section{Results}

A total of 747 cases of AFP were reported in Poland (Fig. 1) between 1999-2014. Stool specimens were collected from patients with paralysis and their close

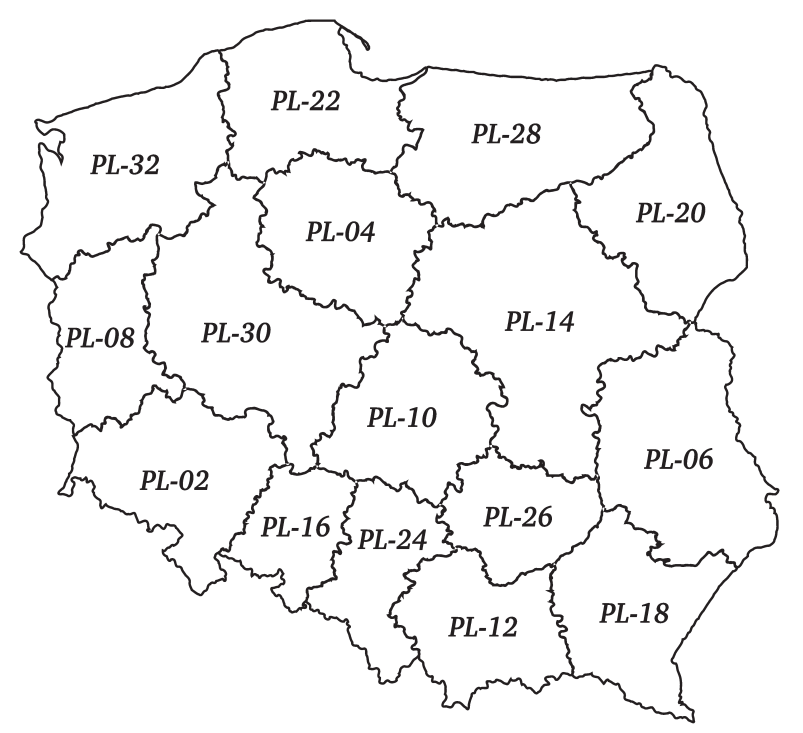

Fig. 1. Map of Poland reflecting study area. 


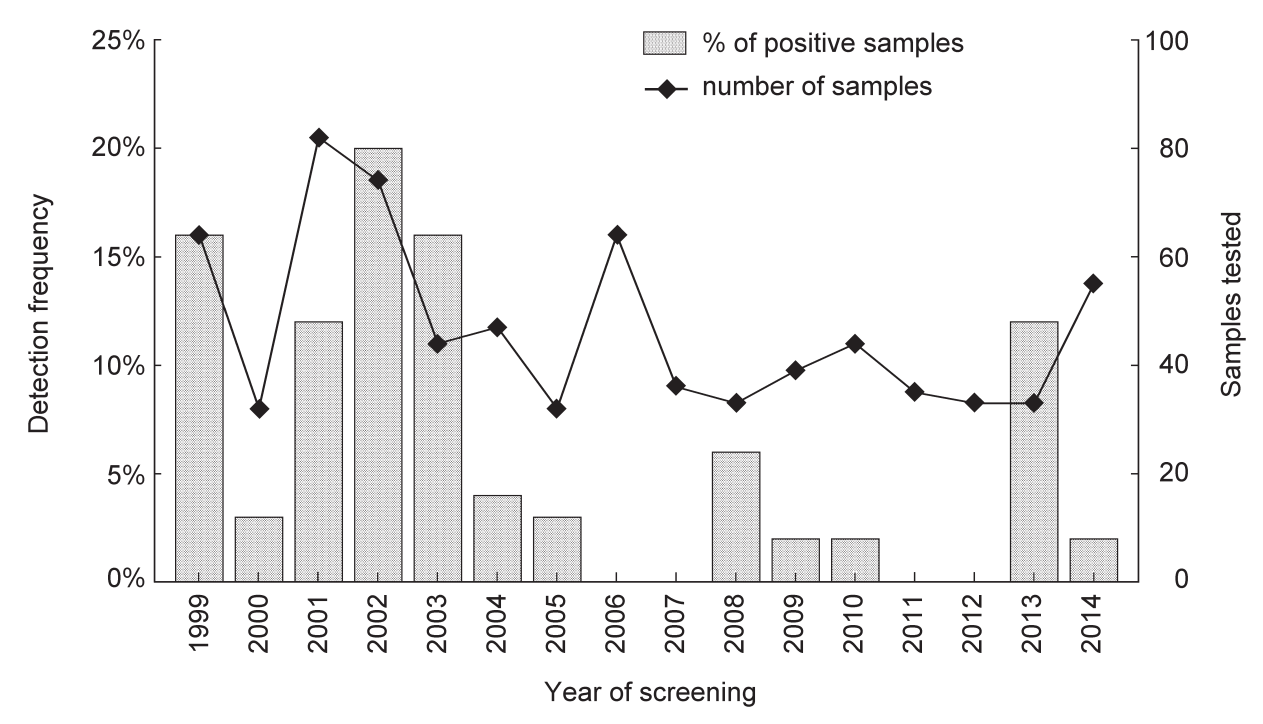

Fig. 2. Detection frequency of enterovirus (polio and non-polio) in patients with acute flaccid paralysis, 1999-2014.

contacts and sent to the National Polio Laboratory in Warsaw. Fifty five $(6.12 \%)$ cases of AFP were associated with enterovirus isolation from patients or their close contacts. Out of the 55 positive cases, 40 were associated with detection of enterovirus in patient, and 15 with detection of EV in healthy contact, without positive detection in paralytic patient. Out of the 40 positive specimens from patients with paralysis, 23 were identified as PVs, 14 as NPEVs, and 3 were identified as a mixture of PV and NPEV. Out of the 15 cases with positive enterovirus detection in healthy contacts, 8 were identified as PVs, 6 as NPEVs and 1 as a mixture of PV and NPEV.

The percentage of positive AFP cases varied from year to year, between $0 \%(2006,2007,2011,2012)$ and $20 \%$ (2002). Figure 2 shows the annual distribution of $\mathrm{EV}$ infection cases, confirmed by virus isolation.

During the 16-year study from 1999 to 2014, polioviruses were associated with 35 AFP cases. All PV positive samples produced a cytopathic effect $(\mathrm{CPE})$ both in human rhabdosarcoma (RD) and human poliovirus receptor CD155 expressing recombinant murine (L20B) cells. These isolates were identified as PV by neutralization test, including 5 PV1, 6 PV2, 13 PV3 and 3 mixtures of PV1+PV2+PV3, 5 mixtures of PV1+PV2, 3 mixtures of PV1+PV3. PV isolates were forwarded to the Regional Reference Polio Laboratory. Sequencing and molecular analysis of VP1 coding region in Robert Koch Institute revealed that they were all Sabin strains. No wild polio viruses were identified. From 2000 to 2003, one dose of inactivated polio vaccine (IPV) and five doses of oral polio vaccine (OPV) were recommended in the national immunization program. In 2003, all children received 2 doses of IPV and 3 doses of OPV. Since 2004, three doses of IPV and one dose of OPV have been used in Poland. From 1999 to
2003, the number of polio positive AFP cases (31) was significantly higher than from 2004 to 2014 (4) $(p=0,001)$. The average annual incidence of vaccineassociated paralytic poliomyelitis (VAPP) in 2004-2014 was 0,36 cases per year.

The results of this study showed that about $43.6 \%$ of positive AFP cases were found in association with the isolation NPEV. From the total collected AFP samples, $25 \mathrm{NPEV}$ s were isolated. Serotyping revealed $15 \mathrm{CVB}$, 1 CVA9, 1 E3, 2 E4, 1 E9, 2 E11, 1 E13, 1 E30 and one additional isolate remains untyped. The most common was CVB (15/25, 60\%). The percentage non-polio positive AFP cases, during the study period, ranged between $0 \%(2006,2007,2009,2010,2011,2012)$ and $9.1 \%$ (2013). There was no significant difference in nonpolio enterovirus positive cases between two periods of analysis (1999-2003 and 2004-2014) ( $\mathrm{p}=0.213)$.

The sequences of isolated strains (region VP1) were compared with all the enterovirus sequences available in GenBank, and the virus isolates to be identified were assigned the serotype of the strain that gave the highest identity score (Table I). The nucleotide identity values for the 25 NPEVs ranged from $90 \%$ to $99 \%$. The results show a wide diversity of species EV-B types. A total of 12 different types were detected (CVA9, CVB1, CVB3, CVB4, CVB5, E3, E4, E9, E11, E13, E30), 10 from AFP cases and 5 from contacts. Three types (E4, CVB3 and CVB5) were detected in cases and contacts, while other isolates were found mainly in one group. Compared to other types, CVA9, CVB1, CVB4, E9, E11, and E30 were significantly associated with AFP (Table I). Among the 12 serotypes, CVB3 and CVB5 were more frequently detected than others, representing $40 \%$ of the characterized isolates, followed by CVB4 (16\%), E4 (8\%), and E11 (8\%). Among the 25 NPEVs, one type of species EV-A was identified. Enterovirus 71 isolated 
Table I

Identification of 25 non-polio enterovirus isolates by BLAST comparisons.

\begin{tabular}{|c|c|c|c|c|c|c|c|}
\hline \multicolumn{3}{|c|}{ AFP strains from Poland } & \multicolumn{5}{|c|}{ Highest scoring strains } \\
\hline $\begin{array}{l}\text { No/Region/year } \\
\text { of isolation } \\
\text { Accession number }\end{array}$ & $\begin{array}{l}\text { Specimen } \\
\text { source }\end{array}$ & Strain & Name & $\begin{array}{c}\text { Accession } \\
\text { number }\end{array}$ & $\begin{array}{l}\% \text { sequence } \\
\text { identity }\end{array}$ & $\begin{array}{l}\text { Country and date } \\
\text { of collection }\end{array}$ & Specimen \\
\hline $\begin{array}{l}\text { 136/PL14/1999 } \\
\text { KU189231 }\end{array}$ & contact & CVB5 & $\begin{array}{l}\text { COPH59346_DNK_02 } \\
\text { CF1107P_FRA_99 }\end{array}$ & $\begin{array}{l}\text { HF948072.1 } \\
\text { HF948032.1 }\end{array}$ & $\begin{array}{l}97 \% \\
94 \%\end{array}$ & $\begin{array}{l}\text { Denmark } 2002 \\
\text { France } 1999\end{array}$ & $\begin{array}{l}\text { stool } \\
\text { throat }\end{array}$ \\
\hline $\begin{array}{l}\text { 348/PL10/1999 } \\
\text { KU189232 }\end{array}$ & contact & CV B5 & $\begin{array}{l}\text { COPH59346_DNK_02 } \\
\text { CF1107P_FRA_99 }\end{array}$ & $\begin{array}{l}\text { HF948072.1 } \\
\text { HF948032.1 }\end{array}$ & $\begin{array}{l}96 \% \\
94 \%\end{array}$ & $\begin{array}{l}\text { Denmark } 2002 \\
\text { Francja } 1999\end{array}$ & $\begin{array}{l}\text { stool } \\
\text { throat }\end{array}$ \\
\hline $\begin{array}{l}\text { 356/PL14/1999 } \\
\text { KU189233 }\end{array}$ & case & CVB5 & $\begin{array}{l}\text { COPH59346_DNK_02 } \\
\text { 2000/CSF/KOR }\end{array}$ & $\begin{array}{l}\text { HF948072.1 } \\
\text { AY875692.1 }\end{array}$ & $\begin{array}{l}96 \% \\
93 \%\end{array}$ & $\begin{array}{l}\text { Denmark } 2002 \\
\text { Korea } 2000\end{array}$ & $\begin{array}{l}\text { stool } \\
\text { CSF }\end{array}$ \\
\hline $\begin{array}{l}\text { 390/PL14/1999 } \\
\text { KU189234 }\end{array}$ & case & E11 & $\begin{array}{l}\text { Jena 799/2002 } \\
\text { S53.98.TUN1998 }\end{array}$ & $\begin{array}{l}\text { DQ092796.1 } \\
\text { HQ674721.1 }\end{array}$ & $\begin{array}{l}95 \% \\
98 \%\end{array}$ & $\begin{array}{l}\text { German } 2002 \\
\text { Tunisia } 1998\end{array}$ & $\begin{array}{l}- \\
\text { stool }\end{array}$ \\
\hline $\begin{array}{l}\text { 616/PL04/2000 } \\
\text { KU189235 }\end{array}$ & case & CVB3 & $\begin{array}{l}\text { Macocy } \\
\text { Nancy }\end{array}$ & $\begin{array}{l}\text { JQ040513.1 } \\
\text { JX312064.1 }\end{array}$ & $\begin{array}{l}99 \% \\
99 \%\end{array}$ & $\begin{array}{l}\text { China } 2007 \\
\text { USA } 1949\end{array}$ & $\begin{array}{l}- \\
\text { stool }\end{array}$ \\
\hline $\begin{array}{l}\text { 722/PL16/2001 } \\
\text { KU189236 }\end{array}$ & case & CVB4 & $\begin{array}{l}\text { CVB4_CF1561_FRA00 } \\
\text { 08fra96 }\end{array}$ & $\begin{array}{l}\text { HF948089.1 } \\
\text { AF160024.1 }\end{array}$ & $\begin{array}{l}98 \% \\
96 \%\end{array}$ & $\begin{array}{l}\text { France } 2000 \\
\text { France } 1996\end{array}$ & $\begin{array}{l}\text { throat } \\
\text { sewage }\end{array}$ \\
\hline $\begin{array}{l}\text { 1024/PL04/2001 } \\
\text { KU189237 }\end{array}$ & contact & E4 & DuToit & AJ241424.1 & $99 \%$ & France & - \\
\hline $\begin{array}{l}\text { 1026/PL08/2001 } \\
\text { KU189238 }\end{array}$ & contact & CVB5 & Faulkner & AF114383.1 & $99 \%$ & USA 1954 & stool \\
\hline $\begin{array}{l}\text { 1028/PL08/2001 } \\
\text { KU189239 }\end{array}$ & case & E4 & DuToit & AJ241424.1 & $99 \%$ & France & - \\
\hline $\begin{array}{l}\text { 1038/PL24/2001 } \\
\text { KU189240 }\end{array}$ & case & CVB4 & $\begin{array}{l}\text { P234pak92 } \\
\text { 6653net94 }\end{array}$ & $\begin{array}{l}\text { AF160018.1 } \\
\text { AF160022.1 }\end{array}$ & $\begin{array}{l}95 \% \\
95 \%\end{array}$ & $\begin{array}{l}\text { Pakistan } 1992 \\
\text { Netherlands } 1994\end{array}$ & $\begin{array}{l}- \\
-\end{array}$ \\
\hline $\begin{array}{l}\text { 1084/PL18/2001 } \\
\text { KU189241 }\end{array}$ & contact & CVB5 & $\begin{array}{l}\text { Jena804/2002 } \\
\text { CF516_FRA_00 }\end{array}$ & $\begin{array}{l}\text { DQ092797.1 } \\
\text { HF948033.1 }\end{array}$ & $\begin{array}{l}98 \% \\
97 \%\end{array}$ & $\begin{array}{l}\text { Germany } 2002 \\
\text { France } 2000\end{array}$ & $-\overline{C S F}$ \\
\hline $\begin{array}{l}\text { 1130/PL30/2001 } \\
\text { KU189242 }\end{array}$ & case & CVB4 & $\begin{array}{l}\text { P234pak92 } \\
\text { 16723net98 }\end{array}$ & $\begin{array}{l}\text { AF160018.1 } \\
\text { AF160027 }\end{array}$ & $\begin{array}{l}95 \% \\
95 \%\end{array}$ & $\begin{array}{l}\text { Pakistan } 1992 \\
\text { Netherlands } 1998\end{array}$ & $\begin{array}{l}- \\
-\end{array}$ \\
\hline $\begin{array}{l}\text { 1152/PL26/2002 } \\
\text { KU189243 }\end{array}$ & contact & E13 & $\begin{array}{l}\text { E13_CF711_FRA00 } \\
\text { E13_CF1612_FRA00 } \\
\text { S3(1)-1 }\end{array}$ & $\begin{array}{l}\text { HF948099.1 } \\
\text { HF948100.1 } \\
\text { AB501332.1 }\end{array}$ & $\begin{array}{l}98 \% \\
98 \% \\
96 \%\end{array}$ & $\begin{array}{l}\text { France } 2000 \\
\text { France } 2000 \\
\text { Japan } 2002\end{array}$ & $\begin{array}{l}\text { stool } \\
\text { CSF } \\
\text { river water }\end{array}$ \\
\hline $\begin{array}{l}\text { 1414/PL18/2002 } \\
\text { KU189244 }\end{array}$ & case & E9 & $\begin{array}{l}\text { DM } \\
\text { E9_CF315022_FRA04 }\end{array}$ & $\begin{array}{l}\text { AF524867.1 } \\
\text { HF948096.1 }\end{array}$ & $\begin{array}{l}96 \% \\
95 \%\end{array}$ & $\begin{array}{l}\text { Netherlands } 1997 \\
\text { France } 2004\end{array}$ & $\begin{array}{l}- \\
\text { throat }\end{array}$ \\
\hline $\begin{array}{l}\text { 1500/PL12/2002 } \\
\text { KU189245 }\end{array}$ & case & CVB3 & $\begin{array}{l}\text { CBV3-18219-02 } \\
2679\end{array}$ & $\begin{array}{l}\text { AY89673.1 } \\
\text { KJ489414.1 }\end{array}$ & $\begin{array}{l}99 \% \\
94 \%\end{array}$ & $\begin{array}{l}\text { Moldova } 2002 \\
\text { France } 1993\end{array}$ & $\begin{array}{l}- \\
-\end{array}$ \\
\hline $\begin{array}{l}\text { 1595/PL20/2002 } \\
\text { KU189246 }\end{array}$ & contact & CVB3 & $\begin{array}{l}\text { CBV3-18219-02 } \\
2679\end{array}$ & $\begin{array}{l}\text { AY89673.1 } \\
\text { KJ489414.1 }\end{array}$ & $\begin{array}{l}99 \% \\
94 \% \\
\end{array}$ & $\begin{array}{l}\text { Moldova } 2002 \\
\text { France } 1993 \\
\end{array}$ & $\begin{array}{l}- \\
-\end{array}$ \\
\hline $\begin{array}{l}\text { 1718/PL06/2003 } \\
\text { KU189247 }\end{array}$ & case & CVB1 & $\begin{array}{l}\text { 1167438_pmMC } \\
05.316 .1153\end{array}$ & $\begin{array}{l}\text { JN797615.1 } \\
\text { FJ868324.1 }\end{array}$ & $\begin{array}{l}90 \% \\
91 \%\end{array}$ & $\begin{array}{l}\text { Switzerland } 2010 \\
\text { Australia } 2005\end{array}$ & $\begin{array}{l}- \\
-\end{array}$ \\
\hline $\begin{array}{l}\text { 1792/PL02/2004 } \\
\text { KU189248 }\end{array}$ & contact & CVB3 & $\begin{array}{l}\text { CVB3_CF193061_FRA05 } \\
\text { CVB3_CF3109_FRA01 }\end{array}$ & $\begin{array}{l}\text { HF948087.1 } \\
\text { HF948084.1 }\end{array}$ & $\begin{array}{l}96 \% \\
96 \% \\
\end{array}$ & $\begin{array}{l}\text { France } 2005 \\
\text { France } 2001 \\
\end{array}$ & $\begin{array}{l}\text { throat } \\
\text { urine }\end{array}$ \\
\hline $\begin{array}{l}\text { 1864/PL14/2005 } \\
\text { KU189249 }\end{array}$ & contact & E3 & $\begin{array}{l}\text { LR31G7 } \\
\text { E3_CF182018_FRA05 }\end{array}$ & $\begin{array}{l}\text { FJ766334.1 } \\
\text { HF948092.1 }\end{array}$ & $\begin{array}{l}96 \% \\
95 \% \\
\end{array}$ & $\begin{array}{l}\text { Greece } 2005 \\
\text { France } 2005\end{array}$ & $\begin{array}{l}- \\
-\end{array}$ \\
\hline $\begin{array}{l}\text { 2048/PL24/2008 } \\
\text { KU189250 }\end{array}$ & case & CVB3 & $\begin{array}{l}\text { E2012174 } \\
\text { EV_851023_ADAM_NL08 }\end{array}$ & $\begin{array}{l}\text { JX027614.1 } \\
\text { KC893469.1 }\end{array}$ & $\begin{array}{l}98 \% \\
99 \% \\
\end{array}$ & $\begin{array}{l}\text { Taiwan } 2012 \\
\text { Netherlands } 2008\end{array}$ & $\begin{array}{l}- \\
-\end{array}$ \\
\hline $\begin{array}{l}\text { 2055/PL12/2008 } \\
\text { KU189251 }\end{array}$ & case & CVB4 & $\begin{array}{l}\text { CF185005/CSF_4.64_FRA12 } \\
364004-06\end{array}$ & $\begin{array}{l}\text { HG793672.1 } \\
\text { AM711078.1 }\end{array}$ & $\begin{array}{l}93 \% \\
93 \%\end{array}$ & $\begin{array}{l}\text { France } 2012 \\
\text { France } 2006\end{array}$ & $\begin{array}{l}\text { CSF } \\
\text { CSF }\end{array}$ \\
\hline $\begin{array}{l}\text { 2235/PL12/2013 } \\
\text { KT 809227 }\end{array}$ & case & E30 & $\begin{array}{l}\mathrm{ZJ} / \mathrm{WZ}-30 / 11 \\
\mathrm{C} 24 / \mathrm{GD} / \mathrm{CHN} / 2012\end{array}$ & $\begin{array}{l}\text { JX0282231 } \\
\text { KM034795.1 }\end{array}$ & $\begin{array}{l}99 \% \\
98 \% \\
\end{array}$ & $\begin{array}{l}\text { China } 2011 \\
\text { China } 2012 \\
\end{array}$ & $\begin{array}{l}\text { CSF } \\
\text { CSF }\end{array}$ \\
\hline $\begin{array}{l}\text { 2239/PL28/2013 } \\
\text { KU189252 }\end{array}$ & case & EV71 & $\begin{array}{l}\text { EV71/XY4/2011 } \\
\text { JB143090060 }\end{array}$ & $\begin{array}{l}\text { JX0750098 } \\
\text { KC866721.1 }\end{array}$ & $\begin{array}{l}99 \% \\
98 \%\end{array}$ & $\begin{array}{l}\text { China } 2011 \\
\text { China } 2009\end{array}$ & $\begin{array}{l}- \\
\text { stool }\end{array}$ \\
\hline $\begin{array}{l}\text { 2249/PL12/2013 } \\
\text { KU189253 }\end{array}$ & case & CVA9 & $\begin{array}{l}\text { A108/YN/CHN/2009 } \\
\text { CVA9_Alberta_2010 }\end{array}$ & $\begin{array}{l}\text { KM890277.1 } \\
\text { JQ837914.1 }\end{array}$ & $\begin{array}{l}93 \% \\
92 \%\end{array}$ & $\begin{array}{l}\text { China } 2009 \\
\text { Canada } 2010\end{array}$ & $\begin{array}{l}\text { feces } \\
\text { CSF }\end{array}$ \\
\hline $\begin{array}{l}\text { 7667/PL24/2014 } \\
\text { KU189254 }\end{array}$ & case & E11 & $\begin{array}{l}\text { 44626_RU_OMS_2012 } \\
\text { CF216070/CSF_4.20_FRA12 }\end{array}$ & $\begin{array}{l}\text { KP090684.1 } \\
\text { HG793710.1 }\end{array}$ & $\begin{array}{l}97 \% \\
96 \%\end{array}$ & $\begin{array}{l}\text { Russia } 2012 \\
\text { France } 2012\end{array}$ & $\overline{-}$ CSF \\
\hline
\end{tabular}


from AFP case in Poland had the closest genetic relationship with C4 isolates previously identified in China in 2009 and 2011.

To investigate the genetic relatedness of EV-B isolates in Poland to globally circulating types, we performed phylogenetic analyses of partial VP1 sequences with the prototypes representing different types available in the GenBank. Phylogenetic tree was constructed from the aligned nucleotide sequences by using the neighbor-joining method. VP1 sequences obtained from a total of 24 NPEV isolates formed monophyletic clusters with their prototype strains according to their serotype. The tree in Fig. 3 compares the sequences of 72 isolates, 24 from our region, 48 from other countries, and from prototype isolates and previously published sequences in GenBank. Phylogenetic analysis revealed that strains from Poland had the closest genetic relationship with isolates previously identified in Europe (France, Finland, Denmark, Moldova) but also in other parts of the world (Tunisia, China, USA) (Fig. 3).

In the VP1 tree, several serotypes showed subclustering into various groups. Two distinct genogroups were observed for CVB4 and E11. CVB5 and CVB3 demonstrated three subclusters. The other enterovirus serotypes existed as a single genotype throughout our study period.

A total of 5 CVB3 strains were isolated during the AFP surveillance in 1999-2014. Homologous comparison revealed $78.0 \%$ to $98.3 \%$ VP1 nucleotide sequence similarities among themselves, and $78.2 \%$ and $99.4 \%$ with prototype strain Nancy. A total of 5 strains of CVB5 were detected during the study period. Homologous comparison revealed $77.0 \%$ to $98.9 \%$ VP1 nucleotide sequence similarities among themselves, and $77.1 \%$ to $99.9 \%$ with prototype strain Faulkner. The comparison of CVB4 strains revealed 89.9 to $98.9 \%$ VP1 sequence similarities among themselves, and $82.3 \%$ to $83.3 \%$ with prototype strain J.V.B. Benschoten.

\section{Discussion}

The Global Polio Eradication Initiative has succeeded in reducing the circulation of wild poliovirus. Europe was declared polio-free in 2002. The last indigenous WPV in Poland was isolated in 1984 (Jarząbek et al., 1992). However, AFP surveillance is still of great importance in monitoring re-emergence of WPV poliomyelitis and emergence of vaccine-derived polioviruses. During AFP surveillance in Poland from 1999 to 2014 , polioviruses were associated with $35(4.7 \%)$ cases of AFP. The findings confirmed all cases as Sabine-like polioviruses. The isolation of these strains indicates vaccine-associated paralytic poliomyelitis. All 3 serotypes of Sabine polioviruses were found with type 3 being the dominant. This serotype frequently causes of VAPP (Vaccine Associated Paralytic Poliomyelitis) (Kapusinszky et al., 2010). The higher rate of PV detection during the period 1999-2004 likely results from the extensive use of OPV up to 2004. During the past 11 years, OPV has been used only as a booster dose after a sequential schedule of IPV. The risk of VAPP varies by doses of OPV vaccine. Most studies have shown that two doses of IPV induce protective levels of antibodies in $90 \%$ or more recipients, which should reduce the incidence of VAPP after OPV administration.

In addition to PVs, 25 NPEVs have been isolated during the AFP surveillance conducted in Poland from 1999 to 2014 . The result of our study suggested that about $3.2 \%$ of AFP cases are found to be associated with isolation of only NPEV. According to the guidebook issued by the WHO, during 1967-1970, just less than $1 \%$ of the patients who were infected with NPEVs showed paralysis. The WHO reported a same percent of non-polio enteroviral AFP during 2000-2003. Scottish researchers reported isolation of coxsackie virus in $15.6 \%$ patients with paralysis during 1956-1973 (Grist and Bell, 1984). Australia showed that $15 \%$ of AFP in 1963 caused by NPEVs. Nigeria has also reported that $14.6 \%$ of AFP during 2002-2003 was caused by NPEV (Mehrabi etal., 2011). Reports of NPEV isolation rate among AFP cases in Asian countries varied from below $10 \%$ in Malaysia and the Philippines (Apostol et al., 2012), to as high as $30 \%$ in India from 2007 to 2009 (Kapoor et al., 2001). The annual NPEV isolation rate in most tropical countries typically exceeds $10 \%$, but the variability of findings influenced by a number of factors, including the season of the year, elevation, or population hygienic levels.

Isolation of NPEVs from AFP cases is common worldwide, but clinically it is difficult to determine their association with paralytic disorders. Although detection of one of the NPEV types during the course of AFP may not provide a proof of a causal relationship, the etiological role of NPEV associated with this syndrome also may not be ruled out.

The predominance of EV-B species found in this study was similar to that of the recent reports described for NPEV strains from hospitalized children and AFP cases from India, Nigeria and Philippines (Laxmivandana et al., 2013; Oyero et al., 2014). In total 12 different types were detected, 6 serotypes of echoviruses, 1 serotype of CVA and 4 CVB serotypes. The enteroviruses reported in this study (CVA9, CVB1, CVB3, CVB4, CVB5, E3, E4, E9, E11, E13, E30) have been earlier isolated in different countries from patients with AFP. Among the 12 serotypes, CVB were more frequently detected than others, representing $60 \%$ of the characterized isolates. CVB and E6, E9, E11 have been also found to be prevalent in AFP cases from India 


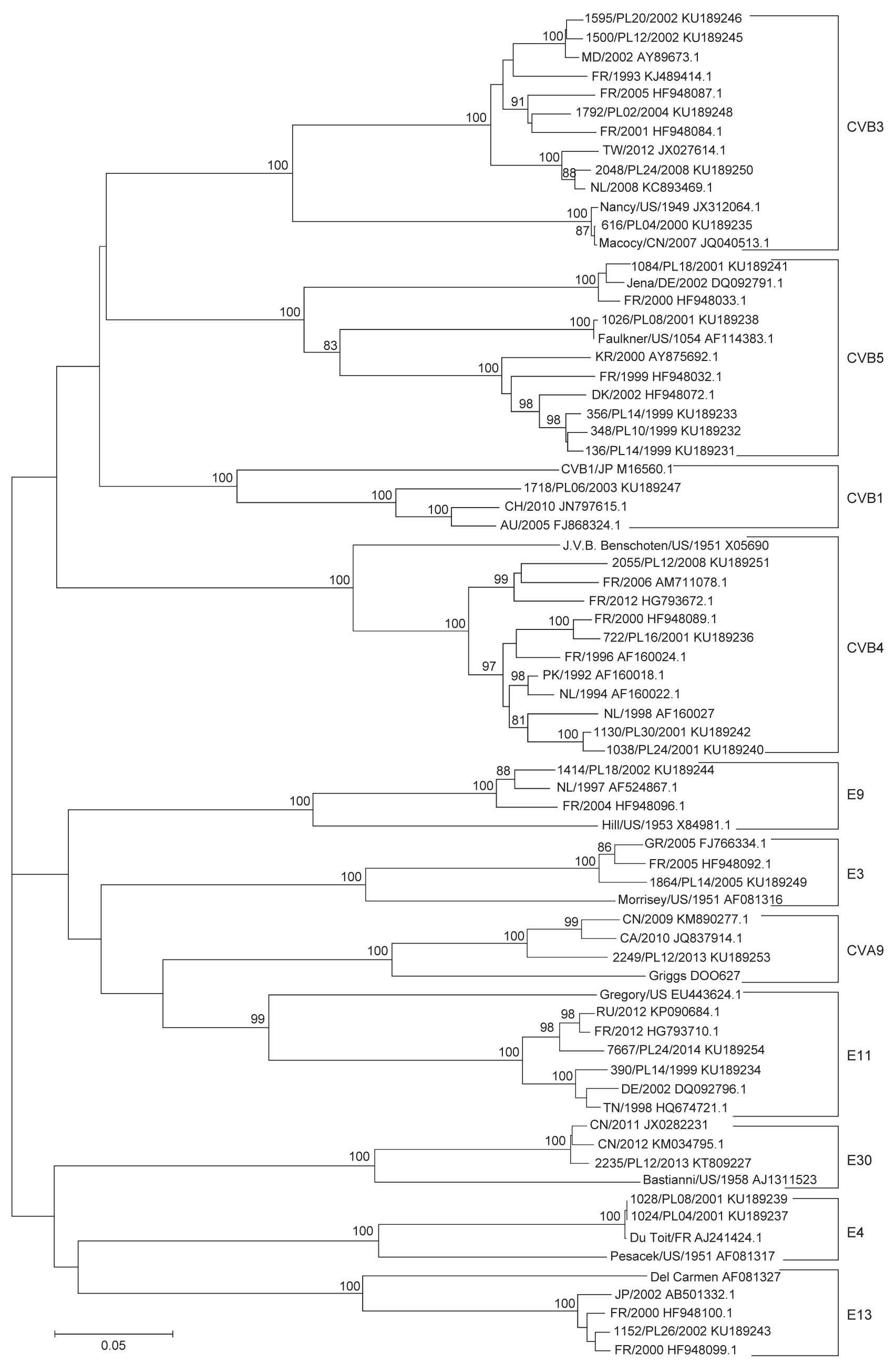


Fig. 3. Phylogenetic tree depicting the relationships between partial capsid gene sequences of 24 Polish NPEVs isolated from 1999 to 2015 and 48 sequences from GenBank. Each strain is referenced by its geographical origin and its accession number. The tree was constructed by the neighbour-joining method and evaluated with 1000 bootstrap pseudoreplicates. Only bootstrap values $\geq 80 \%$ are indicated. In the analyses, genetic distances were calculated with Kimura 2-parameter algorithm. Analyses were conducted in MEGA 6.06 (Tamura et al., 2013).

and other countries (Kapoor et al., 2001; Bahri et al., 2005; Dhole et al., 2009). Most of the detected serotypes of NPEV during AFP surveillance in Poland were also found in sewage. E3, E11 and CVB were the predominant serotypes detected in raw sewage in Poland in 2011 (Wieczorek et al., 2015).

The enteroviruses reported in this study were also found in stools of healthy persons. In Ghana, CVB, E13 and E7 were detected in healthy school children (Odoom et al., 2013). Echovirus 30, E33, E12, E25 and CVA were isolated from healthy family members in Mongolia (Kuramitsu et al., 2005) and E6, E11, E9 and CVB were found among healthy children in India and Egypt (Dhole et al., 2009; Attoh etal., 2014). Healthy children are known to be the major reservoir for enteroviruses in the community.

All the typing results were confirmed by phylogenetic analysis including VP1 sequences of the EV prototype isolates. Analysis of VP1 gene sequences of NPEV strains is widely carried out to determine the EV species and genotypes that circulate in the population. For most enterovirus serotypes, a clear correlation between genetic variability and pathogenic phenotype has not yet to be established. The same virus strain may induce either a clinical disease or an asymptomatic infection. Phylogenetic analysis revealed that strains from Poland had the closest genetic relationship with isolates previously identified in Europe but also in other parts of the world.

This is the first report of the occurrence of EV-71 in Poland. The Polish strain was the closest related to sublineage C4 strains isolated in China. The C4 subgenotype has predominantly been identified in large outbreaks of hand, foot and mouth disease in Asia, where severe cases and a rather high mortality rate have been reported. In 2004 the C4 subgenotype was detected for the first time in Europe (Mirand et al., 2010).

The limitation of this study include lack of true controls as only contacts of AFP cases were tested, which are likely to share exposures and consequently viral flora, with cases. In addition, stool is not the optimal specimen for enterovirus disease association studies due to the high proportion of asymptomatic infections and because disease generally affects other organ systems. The study has some limitations for NPEV surveillance as the focus of the WHO is to detect PVs. The two cell lines recommended for PV isolation (RD and L20B) are less suitable for isolation of NPEVs. Some EV strains that cannot be propagated in RD may have been underdetected and the growth of the other EV types may have been favored (Hosoya et al., 2002). Until now, no cell line has been identified to isolate all the existing NPEV types.

This study suggests that NPEVs, particularly those within the species EV-B may play a contributing role in the etiology of AFP in the country, highlighting the fact that as polio eradication is closing up, improved efforts should be focused on surveillance of NPEVs. After the eradication of poliomyelitis, AFP cases negative for wild poliovirus, but positive for NPEV will continue to be detected. The results of this study indicate that characterization of NPEV isolates could provide better understanding of the epidemiology of NPEV causing paralysis.

\section{Acknowledgments}

This research was undertaken as part of 9/EM.1/2015. The authors thank Anna Diuwe for her technical assistance and Tobiasz Wieczorek for his help with the figures.

\section{Literature}

Angez M., S. Shaukat, R. Zahra, A. Khurshid, S. Sharif, M.M. Alam and S.S. Zaidi. 2015. Molecular epidemiology of enterovirus B77 isolated from non polio acute flaccid paralytic patients in Pakistan during 2013. Infect. Genet. Evol. 29: 189-195.

Apostol L.N., A. Suzuki, A. Bautista, H. Galang, F.J. Paladyn, N. Fuji, S. Lupisan, R. Olveda, and H. Oshitani. 2012. Detection of non-polio enteroviruses from 17 years of virological surveillance of acute flaccid paralysis in the Philippines. J. Med. Virol. 84: 624-631. Attoh J., E. Obodaj, T. Adiku and J.K. Odoom. 2014. Prevalence of human enteroviruses among apparently healthy nursery school children in Accra. Pan. Afr. Med. J. 18: 66.

Bahri O., D. Rezig, B.B. Nejma-Oueslati, A.B. Yahia, J.B. Sassi, N. Hogga, A. Sadraoui and H. Triki. 2005. Enteroviruses in Tunisia: virological surveillance over 12 years (1992-2003). J. Med. Microbiol. 54: 63-69.

Dhole T.N., A. Ayyagari, R. Chowdhary, A.K. Shakya, N. Shrivastay, T. Datta and V. Prakash. 2009. Non-polio enteroviruses in acute flaccid paralysis children of India: vital assessment before polio eradication. J. Paediatr. Child. Health 45: 409-413.

Grist N.R. and E.J. Bell. 1984. Paralytic poliomyelitis and nonpolio enteroviruses: studies in Scotland. Rev. Infect. Dis. 6: 385-386.

Halim S. and A.I. Ramsingh. 2000. A point mutation in VP1 of coxsackievirus B4 alters antigenicity. Virology 269:86-94.

Hosoya M., H. Ishiko, Y. Shimada, K. Honzumi, S. Suzuki, K. Kato and H. Suzuki. 2002. Diagnosis of group A coxsackieviral infection using polymerase chain reaction. Arch. Dis. Child. 87: 316-319. Jarząbek Z., J. Żabicka, A. John, J. Howlett, G. Dunn and D.J. Wood. 1992. Application of monoclonal antibody panels in the virological and epidemiological review of poliomyelitis in Poland, 1981-1990. Bull World Health Organ. 70: 327-333. 
Kapoor A., A. Ayyagari and T.N. Dhole. 2001. Non-polio enteroviruses in acute flaccid paralysis. Indian J. Pediatr. 68: 927-929.

Kapusinszky B., Z. Molnar, K.N. Szomor and G. Berencsi. 2010. Molecular characterization of poliovirus isolates from children who contracted vaccine-associated paralytic poliomyelitis (VAPP) following administration of monovalent type 3 oral poliovirus vaccine in the 1960s in Hungary. FEMS Immunol. Med. Microbiol. 58: 211-217.

Kuramitsu M., C. Kuroiwa, H. Yoshida, M. Miyoshi, J. Okumura, H. Shimizu, L. Narantuya and D. Bat-Ochir. 2005. Non-polio enterovirus isolation among families in Ulaanbaatar and Tov province, Mongolia: prevalence, intrafamiliar spread, and risk factors for infection. Epidemiol. Infect. 133: 1131-1142.

Lang M., A. Mirand, N. Savy, C. Henquell, S. Maridet, R. Perignon, A. Labbe and H. Peigue-Lafeuille. 2014. Acute flaccid paralysis following enterovirus D68 associated pneumonia, France, 2014. Euro. Surveill. 19:pii: 20952.

Laxmivandana R., P. Yergolkar, V. Gopalkrishna and S.D. Chitambar. 2013. Characterization of the non-polio enterovirus infections associated with acute flaccid paralysis in South-Western India. PLoS One 8(4): e61650.

Leitch E.C., H. Harvala, I. Robertson, I. Ubillos, K. Templeton and P. Simmonds. 2009. Direct identification of human enterovirus serotypes in cerebrospinal fluid by amplification and sequencing of the VP1 region. J. Clin. Virol. 44: 119-124.

Liu C.C., H.W. Tseng, S.M. Wang and I.J. Su. 2000. An outbreak of enterovirus 71 infection in Taiwan, 1998. J. Clin. Virol. 17: 23-30. Mehrabi Z., S. Shahmahmoodi, M.R. Eshraghian, H. Tabatabaie, M. Yousefi, Y. Mollaie, Z.S. Eshkiki, T.M. Azad and R. Nategh. 2011. Molecular detection of different types of non-polio enteroviruses in acute flaccid paralysis cases and healthy children, a pilot study. J. Clin. Virol. 50: 181-182.

Mirand A., I. Schuffenecker, C. Henquell, G. Billaud, G. Jugie, D. Falcon, A. Mahul, C. Archimbaud, E. Terletskaia-Ladwig,
S. Diedrich and others. 2010. Phylogenetic evidence for a recent spread of two populations of human enterovirus 71 in European countries. J. Gen. Virol. 91: 2263-2277.

Odoom J.K., E. Obodai, J.S. Barnom, M. Ashun, J. Arthur-Quarm and M. Osei-Kwasi. 2012. Human Enteroviruses isolated during acute flaccid paralysis surveillance in Ghana: implications for the post eradication era. Pan. Afr. Med. J. 12:74.

Ooi M.H., S.C. Wong, D. Clear, D. Perera, S. Krishnan, T. Preston, P.H. Tio, H.J. Willison, B. Tedman, R. Kneen and others. 2003 Adenovirus type 21-associated acute flaccid paralysis during outbreak of hand-food and mouth disease in Sarawak, Malaysia. Clin. Infect. Dis. 36: 550-559.

Oyero O.G., F.D. Adu and J.A. Ayukekbong. 2014. Molecular characterization of diverse species enterovirus B types from children with acute flaccid paralysis and asymptomatic children in Nigeria. Virus Res. 189: 189-193.

Saad M., S. Youssef, D. Kirschke, M. Shubair, D. Haddadin, J. Myers and J. Moorman. 2005. Acute flaccid paralysis: the spectrum of a newly recognized complication of West Nile virus infection. J. Infect. 51: 120-127.

Shaukat S., M. Angez, M.M. Alam, S. Sharif, A. Khurshid, T. Mahmood and S.S. Zaidi. 2013. Characterization of a nove enterovirus serotype and an enterovirus EV-B93 isolated from acute flaccid paralysis patients. PloS One 8:e80040.

Tamura K., G. Stecher, D. Peterson, A. Filipski and S. Kumar 2013. MEGA6: molecular evolutionary genetics analysis version 6.0. Mol. Biol. Evol. 30: 2725-2729.

WHO. 2004. Polio laboratory manual. WHO/IVB/04.10. World Health Organization, Geneva, Switzerland.

WHO. 2015. Enterovirus surveillance guidelines. World Health Organization, Copenhagen, Denmark.

Wieczorek M., A. Ciąćka, A. Witek, Ł. Kuryk and A. Żuk-Wasek. 2015. Environmental surveillance of non-polio enteroviruses in Poland, 2011. Food Envirol. Virol. 7(3): 224-231. 